\title{
The possibility of predicting the collision of trees with construction investments
}

\author{
Edyta Rosłon-Szeryńska ${ }^{1,}{ }^{*}$, Jan Łukaszkiewicz, and Beata Fortuna-Antoszkiewicz \\ ${ }^{1}$ Warsaw University of Life Science, Department of Landscape Architecture, Poland
}

\begin{abstract}
The authors of this article propose that organic architecture is based on a broadly understood prediction of the impact a constructed building will have on the condition of adjacent trees. One of the key issues is deciding if a tree may be left near a constructed facility based on an assessment of the impact the structure will have on tree health and its survival chances. This article presents selected aspects of predicting collisions of buildings with trees based on tree growth prediction. This material presents a case study: predicting the collision of Betula pendula and Tilia cordata with a building development, erected closer than $2.5 \mathrm{~m}$ from their tree trunks.
\end{abstract}

\section{Introduction}

The authors of this article propose that organic architecture which relies on the symbiosis between buildings and environment [1] is based on a multi-faceted prediction of the impact an erected building will have on the condition of adjacent trees. The reaction of a tree to damage may be instantaneous or postponed, even by a few years, which depends on many factors. Construction and renovation works cause necrosis to approx. $20-40 \%$ of trees growing in the direct vicinity [2,3]. In some tree species, colliding with technical infrastructure causes more than a twofold decrease in trunk circumference growth speed compared to specimens growing in normal conditions - not disturbed by technical works has been observed [4]. Mechanical damage stops or slows tree growth and development, as energy reserves are used up to mitigate the impact of stressors and rebuild damaged tissue [5]. To minimize the risk of tree damage, traditionally in the construction industry an optimal Tree Protection Zone (TPZ) is marked out, which usually extends over an area equal to tree crown projection area widened by $1.5-2.0 \mathrm{~m}$, i.e. a zone of increased activity of absorptive roots [2]. For practical reasons, a critical distance of construction works from tree trunk, the so called Root Protection Area (RPA), is also used. This value is calculated not only using trunk diameter and its circumference, but it also addresses tree crown diameter $[6,7]$. According to many sources a tree is threatened by works carried out closer than $2.0 \mathrm{~m}$ from the trunk side surface. However, the minimum distance of works from the tree trunk is between $1.0 \mathrm{~m}$ to $1.2-1.5 \mathrm{~m}[2,8,9]$. This paper covers a case study: assessment of the impact of construction works on the trunk condition of Betula pendula and Tilia cordata tree species growing closer than $2.5 \mathrm{~m}$ from a building facade.

${ }^{*}$ Corresponding author: edyta_roslon_szerynska@sggw.pl 


\section{Scope and methodology}

The study covers common birch (Betula pendula Roth.) and small-leaved lime (Tilia cordata Mill.) specimens (inventory numbers 98-120), growing on a building plot in Konstacin Jeziorna, along the northern facade of an erected one-story utility building with an area of $120 \mathrm{~m}^{2}$, cuboid in shape with a $2 \%$ slope green roof. Based on vegetation inventory and valorisation prepared in 2017, it was determined that 9 birch specimens (numbered 98-106) and 6 lime specimens (numbered 107-112) are in conflict with the erected building (distance smaller than $2.5 \mathrm{~m}$ from facade). The northern edge of building facade is 35.95-211.80 cm away from the tree surface area. Birch no. 98 and lime no. 112 have the most favourable location among the examined trees. The vitality of all the studied trees according to the Roloff [10] vitality scale is equal to " 0 " - trees in the exploration stage. The trees age was estimated at approx. 25-30 years. Based on dendrometric parameters', the limes growing in the research site are in their juvenile stage while the birches have reached maturity. Features for the evaluation of tree resilience to trunk and crown damage have been selected using data from literature (tab. 1).

Table 1. Selected features which can be used for evaluation of resilience to root system damage.

\begin{tabular}{|l|c|c|c|c|}
\hline \multicolumn{1}{|c|}{ tree species } & $\begin{array}{c}\text { wound healing } \\
\text { capacity }\end{array}$ & $\begin{array}{c}\text { susceptibility } \\
\text { to breaking }\end{array}$ & $\begin{array}{c}\text { growth speed in } \\
\text { juvenile stage }\end{array}$ & $\begin{array}{c}\text { maturity } \\
\text { [years] }\end{array}$ \\
\hline Betula pendula & 2 & 3 & 5 & $20-30$ \\
\hline Tilia cordata & 4 & 3 & 3 & $25-40$ \\
\hline
\end{tabular}

Key to scale: 1 - very low, 2 - low, 3 - medium, 4 - high, 5 - very high

The common birch is a short-lived species, characterised by its fast growth and reaching heights of up to 25-30 m, with a narrow, cone or column shaped crown and an excurrent habit. The trunk, reaching height of approx. 12-15 m, often does not have any branches, is cylindrical, and sometimes deformed at its base; in an unfavourable habitat it may also be contorted. At 60-80 years old the tree ceases to grow. The trunk of a birch usually increases in thickness by $1 \mathrm{~cm}$ annually, growing most intensively at the period of 10-20 years. The birch root system is shallow, and sensitive to soil compaction and damage. Birches do not take trimming well. The small-leaved lime is a long-living species growing most intensively at 60-70 years of age. The lime crown is wide, dome-shaped with sagging lower branches. Limes take trimming well, and easily regenerate by growing offshoots [11].

\subsection{Tree growth estimation as part of the assessment of the impact of construction works on trees}

The scope of the study includes an assessment of the impact of planned construction works on the overground part (trunk and crown) of studied tree specimens in their current development stage and over the following 30 years. To determine a possible collision between a building and the overground parts of trees an analytic prognostic model of an increase in diameter at breast height (DBH) of the small-leaved lime as a function of time was used $[12,13,14]$. For this study, the relation of birch DBH to its age was analysed based on empirical data collected by the authors. Critical trunk areas where the distance between a tree and a building may lead to a collision were identified. An analysis of building cross-section drawings indicates that the most collision-prone element of the building is the edge of the ground floor (floor slab) at 30-40 cm, so above the trunk base, a little less than 1 meter below DBH measurement height. Research results show that tree base thickness is on an average $10 \%$ greater than DBH measured at $1.3 \mathrm{~m}$. The authors used this assumption for estimating trunk increments over the following 30 years. 


\subsubsection{Lime growth evaluation method}

The evaluation uses a mathematical exponential model of DBH increments over time developed (1) for street-side small-leaved limes $[13,15]$. It is suitable for predicting DBH increment over time for limes suffering from root system damage caused by construction works. The Presence of a stressor in both cases is crucial (street-side conditions and construction works). The method for estimating the age of a group of trees of the same species using a mathematical model presented in this publication can be used for tree-stands of an unknown age, but which can be reasonably considered as uniform in terms of age structure (the same/similar date of planting of trees of the same age). The exponential regression model presented in this publication is a mathematical formula, the parameters of which have been empirically determined using an appropriate module of STATISTICA 7.0 statistical software and described in numerous publications, e.g. $[13,15]$. The mathematical formula of exponential regression model describing how the age of a groups of trees of similar age relates to the average in this population (median) DBH (argument) is the following:

$$
y=-281,982+2,718^{(5,6555+0,3812 * x)}
$$

$y($ age $)=$ assesed common age for median DBH of even-age group of trees,

$x(\mathrm{DBH})=$ median $\mathrm{DBH}(\mathrm{cm})$ of even-age group of trees,

$r=0,9468$ (regression coefficient) $\rightarrow$ the more its value is closer to 1.0 , the more independent variable $(x)$ get infuence on the dependent variable $(y)$,

$r^{2}=0,8964$ (coefficient of determination) $\rightarrow$ ca. $89 \%$ the variability of age $(y)$ is interpreteded by variability of DBH $(x)$,

$p$ (coefficient of significance) $<0,05 \rightarrow r$ coefficient is statistically significant.

\subsubsection{Birch growth evaluation method}

For this study a mathematical exponential regression model defining the relation of age to breast height diameter of the Betula pendula species was developed (2). Dendrometric data for the common birch were collected, among others, during the research task: "Identifying threshold dendrometric parameters of 10-year old trees of selected species for urban treestand management purposes", carried out as part of an internal competition held by the Landscape Architecture Department of WULS in 2011-2012 [14]. This study included taking inventory and making measurements of 64 trees, as well as determining their age. The actual (physical) age of trees was determined by counting the number of tree rings at the tree's base (dendrochronology). Next, for each tree the following data was collected: breast height diameter [cm] - age [years]. This data was used to find any correlation between the two variables. The mathematical exponential regression model formulated using appropriate modules of STATISTICA 7.0 statistical software [13, 14, 15] which defines the relation of a tree`s age to its DBH (argument) is the following:

$$
y=-83,737+\exp (4,4566+0,0101838 * x)
$$

$y($ age $)=$ assesed common age for median DBH of even-age group of trees,

$x(\mathrm{DBH})=$ median DBH $(\mathrm{cm})$ of even-age group of trees,

$r=0,95024 / r^{2}=0,90 / p<0,05$. 


\section{Results and discussion}

\subsection{Assessment of the possible impact of construction works on the overground parts of trees}

As part of the assessment of the impact of an enclosed structure on the overground parts of trees, a simulation showing the current birch distance to a designed building was done, based on the current dendrometric parameters (such as: height, crown base height, crown diameter, and $\mathrm{DBH}$ ) and a simulation of changes in distance over 30 years by using the values of annual DBH increments of the studied trees using the Łukaszkiewicz birch and lime DBH increment regression model $[13,14]$. The height of the studied birches is in the range of 15.0-17.0 m. As per species parameters, the crown base is set high. The first branches start at 7.0-8.0 m. The average tree breast height diameter is $23 \mathrm{~cm}$, and the crown diameter $9.0 \mathrm{~m}$. The average crown diameter of the studied limes is $11.0 \mathrm{~m}$ and is larger than the crowns of birches. The crown base is at $4.0 \mathrm{~m}$, with the lower branches sagging at $3.2 \mathrm{~m}$ above ground level. The average lime DBH is $22 \mathrm{~cm}$; the average height $-14.0 \mathrm{~m}$.

The constructed building's height including the terrace on a pile foundation is $405 \mathrm{~cm}$. Due to the necessity of carrying out construction and finishing works on the flat roof, an additional $2.0 \mathrm{~m}$ of free space needs to be added to this height. The total free space necessary to erect the building does not collide with the birch crowns, the base of which is located higher. However, the lower branches of limes need to be removed. The authors analysed whether the proximity of the constructed building to the trunks of the studied trees may result in a collision damaging the tree or the building. Currently, the distance between the most protruding roof and green roof elements and the centre location of birches no. 99106 is in the range of $47.5 \mathrm{~cm}-88.05 \mathrm{~cm}$; while the distance between the side surfaces of tree trunks and the building facade measured at $30-40 \mathrm{~cm}$ is in the range from 35.95 to $74.75 \mathrm{~cm}$. Birches located furthest from the building facade are $220 \mathrm{~cm}$ away. The trunk side-surfaces of those trees are approx. $206 \mathrm{~cm}$ away from the nearest protruding building edges. The results of the birch DBH increment analysis are presented in Table 2. The distance between the most protruding building elements and the centre location of limes is in the range of $83 \mathrm{~cm}-225 \mathrm{~cm}$, while the distance between the side surfaces of the tree trunks and building facade measured at $30-40 \mathrm{~cm}$ is in the range from 70.3 to $211.8 \mathrm{~cm}$. This distance ensures safety only if the main tree trunk is additionally protected from vibration caused by gales. The results of the lime DBH increment analysis are presented in Table 2. Considering the current age (25-30 years) and the natural increase of thickness of trees, it is necessary to carry out a prognosis and assessment of the impact this change in distance between the trees and a building facade will have.

The adopted mathematic model allows an estimation of an average age of a birch group at approx. 25 years (with an error of ca. $\pm 10 \%$ specified for the mathematical model based on the coefficient of determination $r^{2}=$ ca. 0.9). Based on this result, it was assumed that the average age of a birch group after 10 years, will be 35 years, and then 45 and 55 years. It was determined that the average DBH of the studied 35-year old birches will equal 28 $\mathrm{cm}$, 45-year old birches $-32 \mathrm{~cm}$ and 50-year old birches $-33 \mathrm{~cm}$. Based on a median lime group DBH its age can be estimated at approx. 30 years with an error of ca. $\pm 11 \%$ specified for the mathematical model based on the coefficient of determination $r^{2}=$ ca. 0.8964). Based on this result, it was assumed that the average age of a lime group after 10 years will be 40 years, and then 50 and 60 years. The average DBH of the studied 40 -year old smallleaved limes will be $31 \mathrm{~cm}, 50$-year old limes - $40 \mathrm{~cm}$, and 60 -year old limes $-47 \mathrm{~cm}$. In terms of methodology, determining an average, estimated age for tree groups of a similar but unknown age allows attaining the highest precision compared to other methods of age estimation. Estimating the age for individual specimens may yield only general results with 
a high margin of error. Table 2. presents the results of an analysis of the change in distance between the side surfaces of the trunks of the studied trees measured at the trunk base at 30$40 \mathrm{~cm}$ in height and the most protruding edge of the building being constructed using tree thickness growth during the next three decades predicted with the above-mentioned mathematical models. Assuming the DBH increment of birches and limes in accordance with the exponential regression model $[12,15]$ and the age table $[16,17]$ in 10 years, the distance of trunk side surfaces to the building will decrease by $5.5-6 \%$. The growth of limes will be slower than birches in this period. For birches, in 10 years the average distance of the trunk side surface to the building facade will equal $47.7 \mathrm{~cm}$ and will be in the range from $33.2 \mathrm{~cm}$ (for tree no. 101) to $204.05 \mathrm{~cm}$ (for tree no. 98). In 20 years this distance will decrease by $10.5 \%$ compared to the current one with the average distance between the trunk side surface and the most protruding edge of the constructed building equal to $45.2 \mathrm{~cm}$. The distance between the trunk of tree no. 101 and the facade will be reduced to $31 \mathrm{~cm}$. In 20 years the distance between over $60 \%$ of the studied birches to the building facade will become smaller than $50 \mathrm{~cm}$. Such a small distance may result in the building or tree damage even if risk mitigation measures are used. However, none of the studied trees will come into contact with the building in the next 20 years. Due to a lack of data, the exponential regression model for birches older than 50 years could not be determined. A theoretical model developed on the basis of age tables $[16,17]$ indicates that 50 to 60 -year old birches show slowed DBH increments. Assuming that the studied birches will grow in accordance with the data in the age tables $[16,17]$, where the average DBH of specimens older than 100 years growing in favourable park conditions is $79 \mathrm{~cm}$, it may be concluded that there is no risk of trees coming into contact with the constructed building. However, the distance of 7 trees ( $>70 \%$ of all trees) to the building edge will decrease to a value below $25 \mathrm{~cm}$.

Table 2. Analysis of common birch and small-leaved lime growth in close proximity to a constructed utility building [prep. E. Rosłon-Szeryńska, J. Lukaszkiewicz].

\begin{tabular}{|c|c|c|c|c|c|c|c|c|c|c|c|c|}
\hline 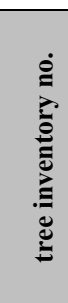 & 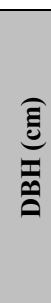 & 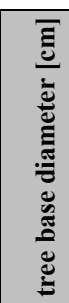 & $\begin{array}{l}\bar{\Xi} \\
\bar{\Xi} \\
\bar{\Xi} \\
\bar{\Xi}\end{array}$ & 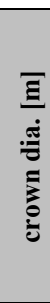 & 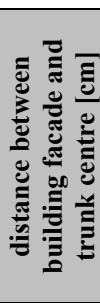 & 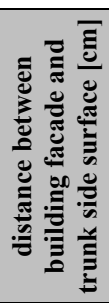 & 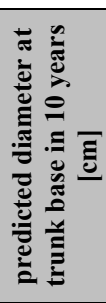 & 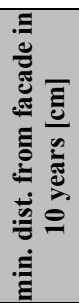 & 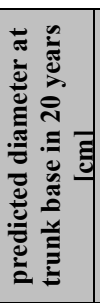 & 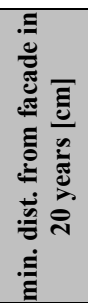 & 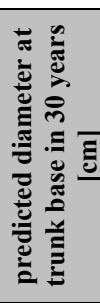 & 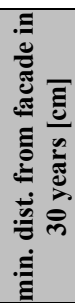 \\
\hline \multicolumn{13}{|c|}{ common birch } \\
\hline $98 a$ & 26 & 28.6 & 17 & 12 & 220 & 206 & 33 & 204 & 37 & 201 & $\mathrm{n} / \mathrm{a}$ & $\mathrm{n} / \mathrm{a}$ \\
\hline $98 b$ & 25 & 27.5 & 17 & 12 & 220 & 206 & 32 & 204 & 36 & 202 & $\mathrm{n} / \mathrm{a}$ & $\mathrm{n} / \mathrm{a}$ \\
\hline 99 & 24 & 26.4 & 17 & 12 & 61 & 47 & 31 & 45 & 35 & 43 & $\mathrm{n} / \mathrm{a}$ & $\mathrm{n} / \mathrm{a}$ \\
\hline 100 & 27 & 29.7 & 17 & 9 & 68 & 53 & 35 & 50 & $\mathrm{n} / \mathrm{a}$ & $\mathrm{n} / \mathrm{a}$ & $\mathrm{n} / \mathrm{a}$ & $\mathrm{n} / \mathrm{a}$ \\
\hline 101 & 21 & 23.1 & 15 & 5 & 48 & 36 & 29 & 33 & 33 & 31 & 37 & 29 \\
\hline 102 & 19 & 20.9 & 16 & 9 & 61 & 50 & 28 & 47 & 33 & 44 & 36 & 42 \\
\hline 103 & 25 & 27.5 & 16 & 10 & 61 & 47 & 32 & 45 & 36 & 42 & $\mathrm{n} / \mathrm{a}$ & $\mathrm{n} / \mathrm{a}$ \\
\hline 104a & 23 & 25.3 & 16 & 11 & 62 & 49 & 31 & 47 & 34 & 45 & $\mathrm{n} / \mathrm{a}$ & $\mathrm{n} / \mathrm{a}$ \\
\hline $104 b$ & 21 & 23.1 & 16 & 11 & 62 & 50 & 29 & 48 & 33 & 46 & 37 & 43 \\
\hline 105 & 25 & 27.5 & 16 & 8 & 89 & 75 & 32 & 73 & 36 & 70 & $\mathrm{n} / \mathrm{a}$ & $\mathrm{n} / \mathrm{a}$ \\
\hline 106 & 18 & 19.8 & 16 & 5 & 77 & 67 & 26 & 63 & 32 & 61 & 35 & 59 \\
\hline Med. & 23 & 25 & 16 & 9 & 93 & 51 & 31 & 48 & 35 & 45 & 37 & 43 \\
\hline
\end{tabular}




\begin{tabular}{|c|c|c|c|c|c|c|c|c|c|c|c|c|c|}
\hline \pm sd & 2.81 & 3.09 & 0.62 & 2.46 & 61 & 60 & 2 & 60 & 2 & 62 & 1 & 11 \\
\hline $\mathbf{1 0 7}$ & 20 & 22.0 & 14 & 10 & 90 & 79 & 31 & 75 & 40 & 70 & 48 & 66 \\
\hline $\mathbf{1 0 8}$ & 23 & 25.2 & 15 & 12 & 83 & 70 & 34 & 66 & 44 & 61 & 52 & 57 \\
\hline $\mathbf{1 0 9}$ & 22 & 24.2 & 14 & 10 & 98 & 86 & 33 & 82 & 43 & 77 & 51 & 73 \\
\hline $\mathbf{1 1 0}$ & 21 & 23.5 & 13 & 9 & 83 & 71 & 32 & 67 & 41 & 63 & 50 & 58 \\
\hline $\mathbf{1 1 1}$ & 22 & 24.2 & 14 & 11 & 130 & 118 & 33 & 114 & 43 & 109 & 51 & 105 \\
\hline $\mathbf{1 1 2}$ & 24 & 26.4 & 15 & 13 & 225 & 212 & 35 & 207 & 44 & 203 & 52 & 199 \\
\hline Med. & $\mathbf{2 2}$ & $\mathbf{2 4 . 2}$ & $\mathbf{1 4}$ & $\mathbf{1 1}$ & $\mathbf{1 1 8}$ & $\mathbf{8 2}$ & $\mathbf{3 3}$ & $\mathbf{7 8}$ & $\mathbf{4 2}$ & $\mathbf{7 3}$ & $\mathbf{5 0}$ & $\mathbf{6 9}$ \\
\hline \pm sd & 1.24 & 1.37 & 0.69 & 1.34 & 50 & 50 & 1 & 50 & 2 & 50 & 1 & 50 \\
\hline
\end{tabular}

Key: \pm sd - standard deviation ; n/a - no data available

risk of tree growing into the building structure - the collision of a tree and building (less than $25 \mathrm{~cm}$ from facade), the tree cannot be preserved during building construction

dangerous proximity to the building, which could result in contact $(26-50 \mathrm{~cm})$, a significant risk of damage, even if risk mitigation measures are applied

very small distance to the building, which could result in contact $(51-75 \mathrm{~cm})$, requires the use of mitigation measures to avoid damage to the building/tree

relatively small distance to the building $(76-100 \mathrm{~cm})$, the recommended use of mitigation measures to avoid damage to the building/tree

small distance of a tree enabling normal growth with proper maintenance $(101-200 \mathrm{~cm})$

relatively safe distance, which allows the normal growth of a tree (more than $200 \mathrm{~cm}$ )

For small-leaved limes in 10 years the average distance of the trunk side surface to the building facade will equal $78 \mathrm{~cm}$ and will be in the range from $65.95 \mathrm{~cm}$ (for tree no. 108) to $207.4 \mathrm{~cm}$ (for tree no. 112). In 20 years this distance will decrease by $11 \%$ compared to the current one with the average distance between trunk side surface and the most protruding edge of the constructed building equal to $73.38 \mathrm{~cm}$. the distance between the trunk of tree no. 108 and the facade will be reduced to $61 \mathrm{~cm}$, and the trunk of tree no. 112 to $203 \mathrm{~cm}$. In 20 years the distance between over $67 \%$ of the studied limes and the building facade will be smaller than $100 \mathrm{~cm}$, but none of the specimens will come closer than $50 \mathrm{~cm}$ to the building. A simulation of the change in tree size after 30 years shows that a normal growth of all trees will be possible, especially if additional measures mitigating the risk of tree and/or building damage are employed. In this time period, the risk of building or tree damage is minute. It is possible that construction of the building will have a further impact on the development and growth of trees. Competing for sunlight and space, tree trunks will not grow cylindrically. Deformations (skewing) will form due to the development of reaction wood as an adaptation to the new habitat conditions. The studied trees (especially limes) are at a small distance from the building but safety may be ensured with the use of elements limiting wind-induced tree vibrations. None of the trees included in the simulations will come into contact with the building.

\subsection{Measures limiting the negative impact of the building on trees}

The study assumed the necessity of minimalizing the negative influence of building foundations on tree roots. Tree roots are least impacted by buildings placed on suspended structures or on micropiles with a diameter up to $300 \mathrm{~mm}$, and spaced not closer than $2.5 \mathrm{~m}$ from each other. Micropiles should be located at least $2.0 \mathrm{~m}$ away from tree trunks. Micropiles should be installed using the least invasive method which does not generate vibrations and does not cause the compaction or crushing of ground layers. During construction works, the overground and underground parts of trees may become damaged. 
According to various sources, the critical extent of trunk damage (including debarking) is equal to more than $50 \%$ of its circumference [18]. In accordance with applicable legal acts, the removal of over $30 \%$ of crown volume constitutes damage to the tree, and removal of more than $50 \%$ of crown volume developed by the tree over its entire lifespan is considered as killing the tree. These values correspond to criteria for damage assessment used for tree valuation trees [6]. These values were used in the study as threshold values of tree damage. The proximity of the constructed building to tree trunks is a major problem. If distance between a tree and the boundary of a building is smaller than $1 \mathrm{~m}$, there is a risk of damage caused by wind-induced tree vibration. This is why using a spacer damper that controls tree trunk movement caused by wind is of crucial importance. This article presents a conceptual design of a structure ensuring the proper distance of a tree from a facade which protects both the trees and the building from mutual damage. The presented design is only conceptual [19]. The building of a prototype is planned to gather additional data. Due to variable wind direction and the possibility of traversal vibrations relative to the facade, it is necessary to determine the correct angle between wooden spacers, arm length and their distance from tree trunks during field observations. The surface of the structure is lined with plastic to protect the tree trunk from damage (Fig. 1, 2).

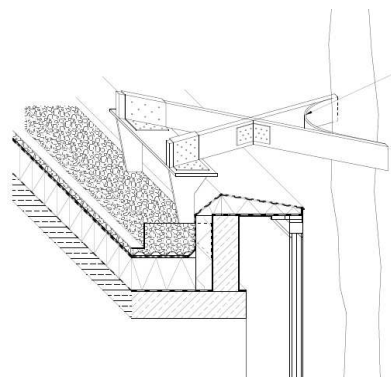

Fig. 1. Axonometric image: spacer damper.

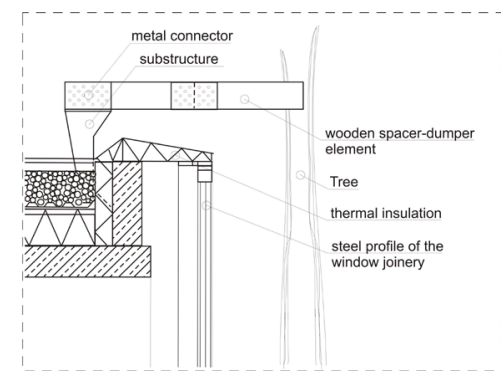

Fig. 2. Cross-section drawing of spacer damper.

\section{Summary and recommendations for tree assessment in the construction process}

With the negative impact of construction works on tree health confirmed by research results, one of the key problems is determining whether the tree may be preserved, relocated or removed based on the assessment of the impact of construction works on tree stability and survival prospects. This publication presents a possible method of making a predictive assessment of the negative impact construction works may have on the overground parts of trees. Arbitrary criteria taking into account species characteristics as well as tree growth and development physiology were used. Using the tree DBH increment exponential regression model [13, 14] authors showed that it is possible to carry out a simulation of tree growth and predict whether a collision will happen if the building is located close to the tree trunk surface area and tree crown. The case study included an analysis of growth over 30 years, that is until the studied common birch and small-leaved lime species (currently 25-30 years old) reach their development stage where intensive growth comes to a halt.

A simulation of tree size change after 30 years shows that the normal growth of all trees will be possible especially if additional measures mitigating the risk to the tree and/or building damage are employed. In this time period, the risk of damage of the building or trees is small. The proximity of a building to tree trunks is a major problem. If the distance 
between a tree and the boundary of a building is less than $1.0 \mathrm{~m}$ there is the risk of damage caused by wind-induced tree vibrations. This is why using a spacer damper controlling tree trunk movement caused by wind is of crucial importance. This aspect will be analysed in further research.

\section{References}

1. L. Klein, Żywe architektury. Analogia biologiczna $w$ architekturze końca XX wieku. Fundacja Kultura Miejsca Warszawa (2014)

2. H. B. Szczepanowska, Drzewa w mieście. (Hortpress, Warszawa, 2001)

3. G. R. Johnson, Protecting Trees from Construction Damage: A Homeowner's Guide (2005), http://treecanada.ca/programs/urbanforestry/cufn/Resources_Non_Canadian/ construction_damage_HomeownersGuide.pdf [access: 15.07.08]

4. B. Fortuna-Antoszkiewicz, J. Łukaszkiewicz, Rocznik Pol. Tow. Denrologicznego Vol. 60, 77-83 (2012)

5. T.T. Kozlowski, Journal of Arboriculture, 11(4), 97-111 (1985)

6. M. Kosmala, E. Rosłon-Szeryńska, M. Suchocka, Ann. Warsaw Univ. of Life Sc. SGGW, Horticult. and Landsc. Architect. 29, 137-144 (2008)

7. M. Kosmala, E. Rosłon-Szeryńska, M. Suchocka, Metoda oceny kondycji drzew z uwzględnieniem bezpieczeństwa i uszkodzeń mechanicznych. IGPIM, Warszawa (2009)

8. N. Matheny, J.R. Clark, Trees and Development A Technical Guide to Preservation of Trees During Land Development. ISA Champaign USA (1998)

9. K.D. Coder, Tree Quality BMPs for Developing Wooded Areas and Protecting Residence Trees [in:] Trees and Building Sites. International Society of Arboriculture, Savoy, Illinois (1995)

10. A. Roloff, Kronenentwicklung und Vitalitätsbeurteilung ausgewählter Baumarten der gemäßigten Breiten. Schriften aus der Forstlichen Fakultät der Universität Göttingen und der Niedersächsischen Forstlichen Versuchsanstalt. Sauerländer, Frankfurt am Main (1989)

11. E. Rosłon-Szeryńska, in: Uprawa i ochrona drzew. Czasopismo Międzynarodowego Towarzystwa Uprawy i Ochrony Drzew, Nr 27, 89 (2012)

12. J. Łukaszkiewicz Ann. Warsaw Agriculi. Univ. - SGGW., Horticult. Land. Architect. No 30: 183-188 (2009)

13. J. Łukaszkiewicz, Rocznik Pol. Tow. Dendrologicznego Vol. 58, 25-38 (2010)

14. J. Łukaszkiewicz, Rocznik Pol. Tow. Dendrologicznego Vol. 61, 87-95 (2013)

15. J. Łukaszkiewicz, M. Kosmala, Arboriculture \& Urban Forestry, 34(3), 137-143 (2008)

16. L. Majdecki.: Tabela wiekowa drzew. Materiały niepublikowane (mp.), SGGW, Warszawa (1980-86)

17. A. Mitchell. A Field Guide to the Trees of Britain and Northern Europe. London (William Collins Sons \& Co. Ltd., 1979)

18. T.T. Kozlowski, Journal of Arboriculture, 11(4), 97-111 (1985)

19. E. Rosłon-Szeryńska, Opinia dendrologiczna dotyczaca oceny wpływu budowy budynku gospodarczego na działce $n r$ ew. 58 z obr. 03-18, leżacej przy ul. Wojewódzkiej $36 \mathrm{w}$ Konstancinie Jeziorna na sasiadujace z budowa zadrzewienia złożone z brzozy brodawkowatej. (Mp) oprac. dla NOKEarchitects Karol Pasternak, Warszawa (2013) 